\title{
Can the negative effects of ketamine abuse on female genital organs be prevented by nimesulide? An experimental study
}

\author{
Can Turkler ${ }^{1}$, Taylan Onat ${ }^{2}$, Engin Yildirim ${ }^{3}$, Selcuk Kaplan ${ }^{4}$, Gulce N. Yazici ${ }^{5}$, Renad \\ Mammadov $^{6}$ and Mukadder Sunar ${ }^{7}$ \\ ${ }^{1}$ Erzincan Binali Yildirlm University Faculty of Medicine, Department of Gynecology and Obstetrics, Erzincan, Turkey \\ ${ }^{2}$ Bozok University Faculty of Medicine, Department of Gynecology and Obstetrics, Yozgat, Turkey \\ ${ }^{3}$ Hitit University Faculty of Medicine, Department of Gynecology and Obstetrics, Corum, Turkey \\ ${ }^{4}$ Adryaman University Faculty of Medicine, Department of Gynecology and Obstetrics, Adryaman, Turkey \\ ${ }^{5}$ Erzincan Binali Yildirım University Faculty of Medicine, Department of Histology and Embryology, Erzincan, Turkey \\ ${ }^{6}$ Erzincan Binali Yildirlm University Faculty of Medicine, Department of Pharmacology, Erzincan, Turkey \\ ${ }^{7}$ Erzincan Binali Yildrrm University Faculty of Medicine, Department of Anatomy, Erzincan, Turkey
}

\begin{abstract}
The objective of this study is to investigate the effects of nimesulide on ketamine-induced ovarian and uterine toxicity by biochemical and histopathological examinations. Ketamine is an anesthetic agent whose use leads to overproduction of catecholamines. Nimesulide is a cyclooxygenase-2 inhibitor, which has also been reported to exert a significant antioxidant effect. Wistar albino female rats were randomly divided into three groups as follows: ketamine group (60 $\mathrm{mg} /$ $\mathrm{kg})$, ketamine $(60 \mathrm{mg} / \mathrm{kg})+$ nimesulide $(50 \mathrm{mg} / \mathrm{kg})$ group, and a healthy control group. Then, the biochemical levels and histopathological findings in the ovaries and uteri of the rats were examined for malondialdehyde, myeloperoxidase, total glutathione and superoxide dismutase. The study demonstrated that, in the uterine and ovarian tissues of rats that have been administered ketamine, there was a decrease in the levels of total glutathione and superoxide dismutase, while malondialdehyde and myeloperoxidase was increased: however it was observed that these ratios were reversed in the ketamine+nimesulide group. It was also proved that the negative effects of ketamine can be corrected with nimesulide when the myometrial and endometrial thicknesses are compared. Antioxidants such as nimesulide may protect against the damage caused by ketamine to the genital organs in young women.
\end{abstract}

Key words: Ketamine - Nimesulide - Ovarian toxicity - Rat - Uterine toxicity

\section{Introduction}

Ketamine is a phencyclidine-derived intravenous anesthetic (Craven 2007). Ketamine has become a drug whose use has been abused in many countries (Weiner et al. 2000). Ketamine abuse and related deaths have increased in recent years. In the case of subanesthetic doses of ketamine, dissociative effects occur called 'fall into K cavity', 'K-chamber' or 'K-land' (Dalgarno and Shewan 1996) and include waking dreams and illusions (Dong et al. 2019). The acute effects

Correspondence to: Can Turkler, Menderes Mah. 127. Sok No: 7 D Blok D:4 Nar Konutları, Demirkent/Erzincan 24000, Turkey E-mail: dr_canturkler@yahoo.com of ketamine disappear within 15 to 45 minute after being administered. However, complications may occur days or weeks after taking ketamine (Freese et al. 2002; Lim 2003). As the tolerance to ketamine develops, the daily dose of ketamine can be increased up to $4 \mathrm{~g}$. This leads to further aggravation of ketamine complications (Lim 2003). In addition, the use of high doses of ketamine may cause complications such as tachycardia and elevated arterial blood pressure, which may adversely affect myocardial function (Craven 2007). It is argued that these toxic effects of ketamine result from sympathomimetic activity (White and Ryan 1996). Ketamine use leads to overproduction of catecholamines (Dalgarno and Shewan 1996; Aksoy et al. 2014). Excess production of catecholamines has been 
reported to cause oxidative tissue damage (Lim 2003; Hašková et al. 2011).

Nimesulide selectively inhibits the enzyme cyclooxygenase-2 (COX-2) (Khan et al. 2011). It has anti-inflammatory, antipyretic and analgesic effects (Suleyman et al. 2008). In published literature, nimesulide has been reported to inhibit endogenous adrenoreceptor (ADR) production (Suleyman et al. 2007). Nimesulide has also been reported to exert a significant antioxidant effect by suppressing oxidative stress, which plays an important role in the pathogenesis of tissue damage (Isaoglu et al. 2012; Demiryilmaz et al. 2014).

The release of reactive oxygen species (ROS) is the major factor in oxidative stress. ROS affect cellular membrane lipids with lipid peroxidation and lead to the formation of malondialdehyde (MDA). MDA can damage both the membrane structure and cell functions. Myeloperoxidase (MPO) enzyme is a lysosomal enzyme secreted from leucocytes as a response to oxidative stress. MPO forms ROS and plays a role in oxidative stress reactions. Some antioxidant enzymes, such as superoxide dismutase (SOD), glutathione peroxidase $(\mathrm{GPx})$ or nonezymatic compounds like glutathione (GSH), protect the tissue from oxidative damage. The balance between ROS and antioxidants determines the severity of oxidative stress (Velioglu et al. 2019). It has been reported that ketamine administration increased oxidant markers including MDA and MPO, whereas nimesulide application has been shown to increase antioxidant parameters including SOD and total glutathione (tGSH) (Arslan et. al. 2016; Ahiskalioglu et al. 2018).

According to the above mentioned information, it was thought that the oxidative tissue damage caused by ketamine through catecholamine synthesis may be prevented by nimesulide by reducing the endogenous adrenoreceptor synthesis. There was no information about the effects of nimesulide on ketamine-induced ovarian and uterine toxicity in the literature reviewed. Therefore, the aim of this study was to investigate the effects of nimesulide on ketamineinduced ovarian and uterine toxicity by biochemical and histopathological investigations.

\section{Materials and Methods}

\section{Animals}

The recommendations of the 'National Institute of Health guide for the care and use of Laboratory animals (NIH Publications No. 8023, revised 1978) were taken into consideration. A total of 18 Wistar albino female rats weighing from 260 to $275 \mathrm{~g}$ were randomly selected for use in the study. Animals were housed and fed at normal room temperature (22 to $24^{\circ} \mathrm{C}$ ) prior to the experiment. This study was car- ried out in accordance with international guidelines on the ethical use of animals (Ethics Committee Date and Number: 22.11.2018-12/212).

\section{Experimental groups}

Rats were randomly divided into three groups as follows: ketamine (60 mg/kg) group (Ket group, $n=6)$, ketamine $(60 \mathrm{mg} / \mathrm{kg})+$ nimesulide $(50 \mathrm{mg} / \mathrm{kg})$ group (Ket+Nim group; $n=6$ ), and a healthy control group (Control group, $n=6$ ). Nimesulide has been shown to be effective in animals at doses ranging from 50 to $100 \mathrm{mg} / \mathrm{kg}$ in the published literature (Demiryilmaz et al. 2014). Therefore, nimesulide was administered to the rats in the Ket+Nim group by oral gavage at a dose of $50 \mathrm{mg} / \mathrm{kg}$. The rats were injected with ketamine at a dosage of $60 \mathrm{mg} / \mathrm{kg}$ intraperitoneally (i.p.), except for the Control group. Because, this dose of ketamine was the maximum effective dose reported to create oxidative stress in rats (Aksoy et al. 2014).

\section{Chemical substances}

The ketamine used in the study was provided by Pfizer (USA), and nimesulide was provided by Sanovel (Turkey).

\section{Experimental procedure}

The rats in the Ket+Nim group were administered nimesulide by oral gavage at a dose of $50 \mathrm{mg} / \mathrm{kg}$. At the same time, the same volume of distilled water was applied to the Ket and Control groups by an oral method. One hour after administration of the nimesulide and distilled water, the rats were injected with ketamine at a dosage of $60 \mathrm{mg} / \mathrm{kg}$ i.p., except for the Control group. Nimesulide, ketamine and distilled water were applied at the indicated dose and volume once a day for 30 days using the same method. At the end of this period, six rats from each group were killed by decapitation. Their ovarian and uterine tissues were removed, and the levels of MDA, MPO, SOD and tGSH were measured. Oxidant and antioxidant parameters were measured to evaluate oxidative stress in both types of tissue. The tissues were also examined histopathologically. Biochemical and histopathologic results were compared between the groups.

\section{Biochemical analysis of ovarian and uterine tissues}

All of the ovarian and uterine tissues were weighed and homogenized on ice with $2 \mathrm{ml}$ of suitable buffer. For the biochemical analysis, $0.5 \%$ hexadecyltrimethyl ammonium bromide (at a $\mathrm{pH}$ 6), and phosphate buffered saline (at a $\mathrm{pH}$ 7.5) were used. Then, they were centrifuged and the supernatant was used for analysis. 


\section{Measurement of MDA}

The measurement of tissue lipid peroxidation was determined by estimating the MDA using the thiobarbituric acid test involving measurement with a spectrophotometer at a wavelength of $532 \mathrm{~nm}$ as used by Ohkawa et al. (1979). The results were expressed as micromol/gram of protein.

\section{Measurement of MPO}

The activity of MPO in the tissue homogenate was analyzed according to the method described by Wei and Frenkel, with some modifications (Bradley et al. 1982). The sample was homogenized with phosphate buffer. A $1.3 \mathrm{ml}$ amount of 4-aminoantipyrine-2\% phenol ( $25 \mathrm{mM})$ solution was added to the tissue homogenate and MPO activity was measured with a spectrophotometer at a wavelength of $412 \mathrm{~nm}$. The results were expressed as Unit/gram of protein.

\section{Measurement of $t G S H$}

The concentration of tGSH in the tissue was measured according to the process described by Sedlak and Lindsay (1968). The tissue homogenate was used to determine GSH using DTNB (5,5'-dithiobis [2-nitrobenzoic acid]). The absorbance was measured with a spectrophotometer at a wavelength of $412 \mathrm{~nm}$. The results were expressed as nanomol/gram of protein.

\section{Measurement of SOD activitiy}

The measurement of the SOD activity was performed according to the method of Sun et al. (1988). SOD is a product of uric acid metabolism, which is controlled by xanthine oxidase. SOD reacts with nitro blue tetrazolium (NBT) and a purple-colored formazan dye occurs. The absorbance of the formazan was measured at a wavelength of $560 \mathrm{~nm}$ using a spectrophotometer. The results were expressed as Unit/ gram of protein.

\section{Histopathological analysis}

The samples of tissues were first treated with a $10 \%$ formaldehyde solution for microscopic evaluation. After that, the samples of tissue were washed under tap water in cassettes for one day. Alcohol at concentrations of 70, 80, 90 and $100 \%$ were applied to the samples, respectively. Tissues were then embedded in paraffin. Five micron sections were prepared and hematoxylin-eosin staining was applied. The histopathological photos were taken using the Olympus DP2-SAL firmware program (Olympus ${ }^{\circledast}$ Inc. Tokyo, Japan) for assessment. The myometrial thickness and the endometrial thickness were duly measured (Teixeira et al. 2014).
The measurements were obtained from six different regions for each layer. The mean value of the measurements was taken and the results were expressed in micrometers $(\mu \mathrm{m})$. Histopathological examination was carried out by a blind reading of the histology.

\section{Statistical analysis}

SPSS 22.0 software was employed for the statistical analysis (SPSS Inc, Chicago, IL). Mean and standard deviation descriptive statistical methods were obtained. Differences among the three groups were evaluated with Tukey analysis. A $p<0.05$ level was considered to be statistically significant.

\section{Results}

All rats completed the study without any fatalities. As seen in Figure 1 (for ovarian tissues), the MDA level in the ovarian tissue was measured to be $1.5 \pm 0.3 \mu \mathrm{mol} / \mathrm{g}$ of protein in the Control group and $4.6 \pm 0.4 \mu \mathrm{mol} / \mathrm{g}$ of protein in the Ket group. When compared to the Control group, the increase in MDA level in the Ket group was significant $(p<0.05)$. A $50 \mathrm{mg} / \mathrm{kg}$ dose of nimesulide reduced the level of MDA $(2.1 \pm 0.3 \mu \mathrm{mol} / \mathrm{g}$ of protein) significantly compared to the Ket group $(p<0.05)$.

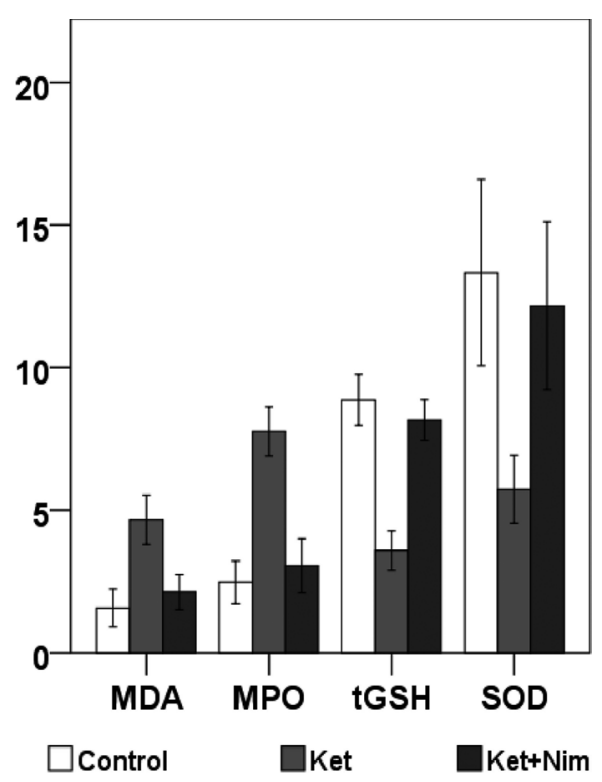

Figure 1. Malondialdehyde (MDA), myeloperoxidase (MPO), total glutathione (tGSH), and superoxide dismutase (SOD) levels of ovarian tissues for 3 groups. Control, healthy control group; Ket, ketamine group; Ket+Nim, ketamine + nimesulide group. Data are mean \pm SD. 
When the other two groups were compared with the Ket group, MPO significantly increased in the Ket group (7.7 \pm $0.4 \mathrm{U} / \mathrm{g}$ of protein), but the value in the Ket+Nim group (3.0 $\pm 0.4 \mathrm{U} / \mathrm{g}$ of protein) was close to the Control group (2.4 \pm $0.3 \mathrm{U} / \mathrm{g}$ of protein) $(p<0.05)$.

Ketamine application significantly decreased the tGSH level in the ovarian tissue of rats compared to the Control group $(p<0.05)$. The tGSH levels were measured to be $8.8 \pm 0.4 \mathrm{nmol} / \mathrm{g}$ of protein in the Control group and $3.5 \pm$ $0.3 \mathrm{nmol} / \mathrm{g}$ of protein in the Ket group. It was found that $50 \mathrm{mg} / \mathrm{kg}$ of nimesulide, by comparison with the Ket group, significantly improved the tGSH level $(8.1 \pm 0.3 \mathrm{nmol} / \mathrm{g}$ of protein) in the Ket+Nim group $(p<0.05)$.

When the other two groups were compared with the Ket group, SOD significantly decreased in the Ket group (5.7 $\pm 0.5 \mathrm{U} / \mathrm{g}$ of protein), but the value in the Ket+Nim group $(12.1 \pm 1.4 \mathrm{U} / \mathrm{g}$ of protein) was close to the Control group $(13.3 \pm 1.6 \mathrm{U} / \mathrm{g}$ of protein $)(p<0.05)$.

As seen in Figure 2 (for uterine tissues), the MDA level in the uterine tissue was measured to be $1.3 \pm 1.1 \mu \mathrm{mol} / \mathrm{g}$ of protein in the Control group and $3.6 \pm 0.2 \mu \mathrm{mol} / \mathrm{g}$ of protein in the Ket group. When compared to the Control group, the increase in MDA level in the Ket group was significant $(p<$ 0.05). A $50 \mathrm{mg} / \mathrm{kg}$ dose of nimesulide reduced the level of MDA $(1.5 \pm 0.2 \mu \mathrm{mol} / \mathrm{g}$ of protein $)$ significantly compared to the Ket group $(p<0.05)$.

When the other two groups were compared with the Ket group, MPO significantly increased in the Ket group (6.9 \pm

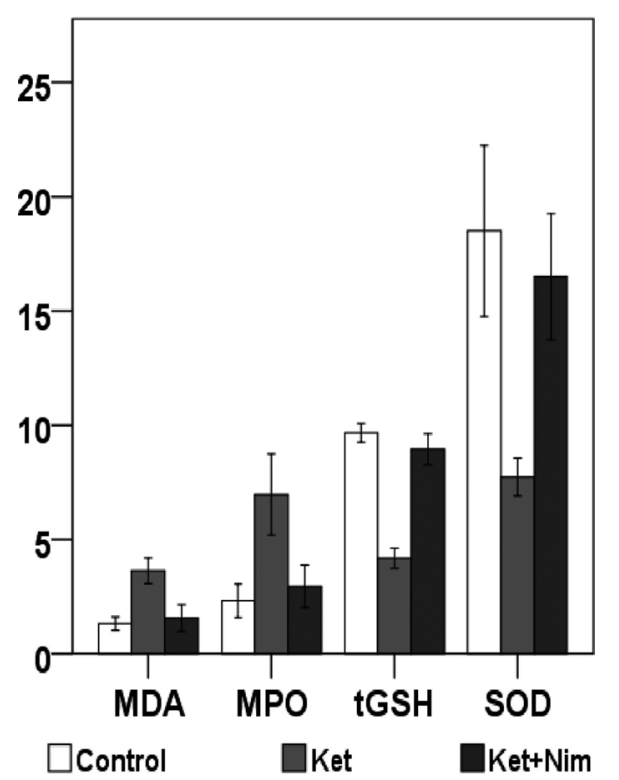

Figure 2. Malondialdehyde (MDA), myeloperoxidase (MPO), total glutathione (tGSH), and superoxide dismutase (SOD) levels of uterine tissues for 3 groups. Control, healthy control group; Ket, ketamine group; Ket+Nim, ketamine+nimesulide group. Data are mean \pm SD.
$0.8 \mathrm{U} / \mathrm{g}$ of protein), but the value in the Ket+Nim group (2.9 $\pm 0.4 \mathrm{U} / \mathrm{g}$ of protein) was close to the Control group (2.3 \pm $0.3 \mathrm{U} / \mathrm{g}$ of protein) $(p<0.05)$.

Ketamine application significantly decreased the tGSH level in the uterine tissue of rats compared to the Control group $(p<0.05)$. The tGSH levels were measured to be $9.6 \pm 0.2 \mathrm{nmol} / \mathrm{g}$ of protein in the Control group and 4.1 $\pm 0.2 \mathrm{nmol} / \mathrm{g}$ of protein in the Ket group. It was found that $50 \mathrm{mg} / \mathrm{kg}$ of nimesulide, by comparison with the Ket group, significantly improved the tGSH level $(8.9 \pm 0.3 \mathrm{nmol} / \mathrm{g}$ of protein) in the Ket+Nim group $(p<0.05)$.

When the other two groups were compared with the Ket group, SOD significantly decreased in the Ket group (7.7 $\pm 0.4 \mathrm{U} / \mathrm{g}$ of protein), but the value in the Ket+Nim group $(16.5 \pm 1.3 \mathrm{U} / \mathrm{g}$ of protein) was close to the Control group $(18.5 \pm 1.8 \mathrm{U} / \mathrm{g}$ of protein) $(p<0.05)$.

Histological examination of ovaries in the Control group revealed that overall ovarian tissue appearence was normal in the cortex and medulla (Figure 3A). In the Ket group, a microscopic examination showed vascular dilation and congestion, explicit polymorphonuclear cell infiltration in developing follicules, intensive edema in follicular cells, especially in the intersititial area (Figure 3B, C). Rats' ovaries treated with nimesulide prior to ketamine showed mild vascular congestion and a normal follicular structure. Intersititial and follicular edema were greatly decreased and polymorphonuclear cell infiltration was not observed in the developing follicules (Figure 3D).

When the uterine tissue was examined, it was observed that all the structures of the uterine tissue were normal in the Control group, and the luminal and glandular epithelium were characterized by simple columnar epithelium (Figure 4A). In the Ket group, the luminal epithelium and glandular epithelium showed localized pericellular edema and degeneration. In addition, mild vascular congestion in the mucosa and inflammatory cell infiltration was observed around the uterine glands. Also vacuolized bodies were observed in the lumen of uterine glands as evidenced by epithelial denudation (Figure 4B, C). In rats' uterine tissues treated with nimesulide prior to the ketamine dose, the uterine luminal and glandular epithelium showed diminished pericellular edema, infrequent vascular congestion in the mucosa and comparatively decreased inflammatory cell infiltration around the uterine glands. Vacuolised bodies were not detected in the lumen of the uterine glands (Figure 4D).

The endometrial thickness (ET) was higher in the Control and Ket+Nim groups compared with the Ket group [Control group $(304.3 \pm 4.7 \mu \mathrm{m})>\operatorname{Ket}+\mathrm{Nim}$ group $(269 \pm 22.2 \mu \mathrm{m})$ $>$ Ket group $(174 \pm 9.7 \mu \mathrm{m}), p<0.05]$; also the myometrial thickness (MT) was higher in the Control and Ket+Nim groups compared to the Ket group [Control group (89.1 \pm $7.9 \mu \mathrm{m})>$ Ket+Nim group $(70.5 \pm 8.7 \mu \mathrm{m})>$ Ket group $(46.5$ $\pm 3.2 \mu \mathrm{m}), p<0.05$ ] (Figure 5). 

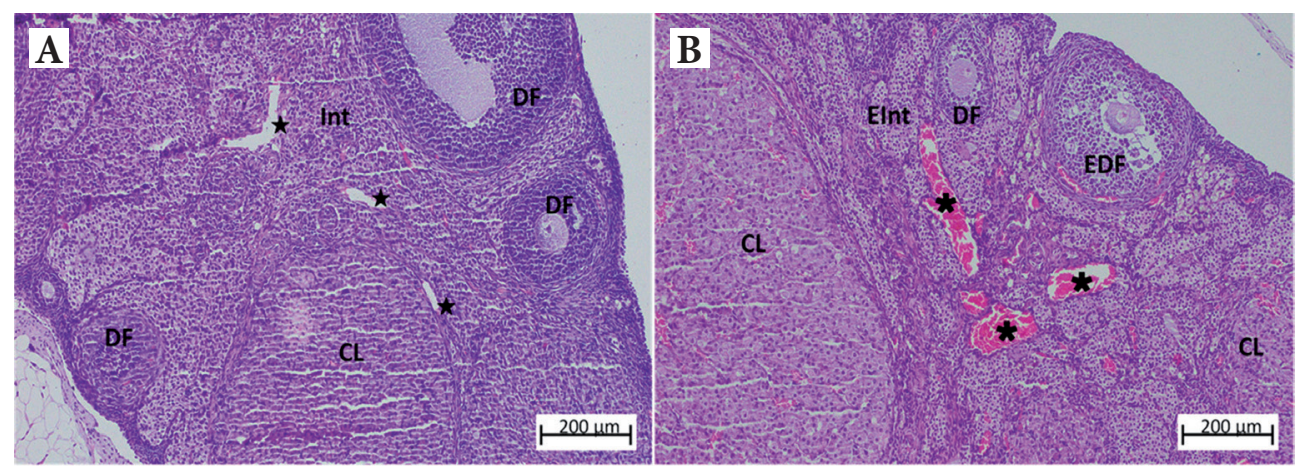

Figure 3. The histological findings of the ovarian tissue. A. Control group (H\&E, 100x magnification). B. Ketamine group (H\&E, 100× magnification). C. Ketamine group
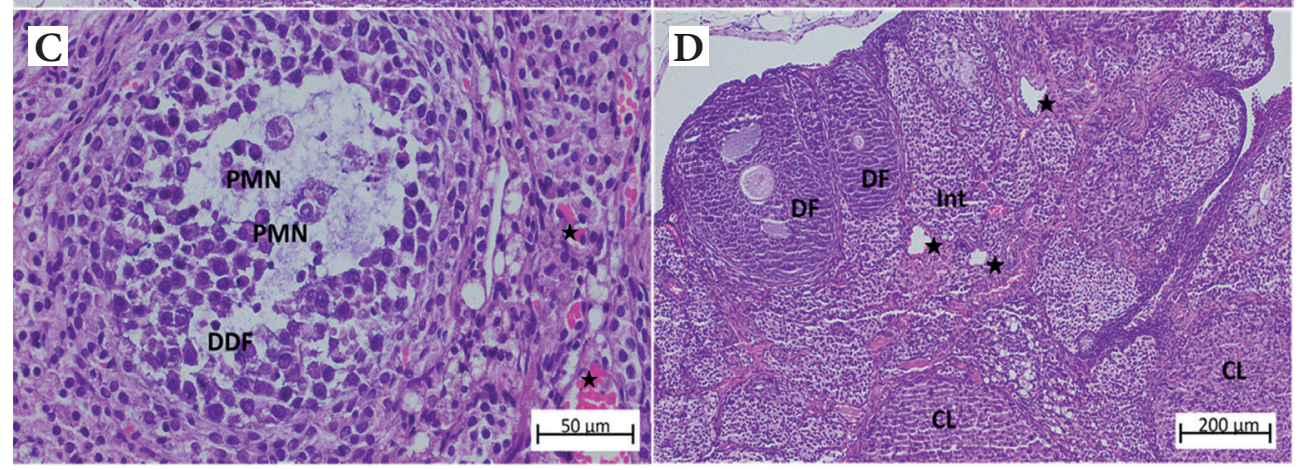
(H\&E, 400× magnification). D. Ketamine+nimesulide group (H\&E, 100× magnification). CL, corpus luteum; DF, developing follicule; DDF, degenerated developing follicule; EDF, edema in developing follicule; EInt, intersititial edema; Int, intersititial area; PMN, polimorphonuclear cell infiltration; $\star$ congested blood vessel.

\section{Discussion}

Ketamine is an anesthetic agent which has been used for amusement by drug abusers in recent years. Abusers are mostly in the younger and fertile age group (Onaolapo et al.
2018). Examining the published literature, numerous animal studies were carried out to prove the effects of ketamine on the organs and systems (Ozturk et al. 2014; Ahiskalioglu et al. 2018; Onaolapo et al. 2018). However, there are no studies on the effects of ketamine on uterus and ovary. The aim of
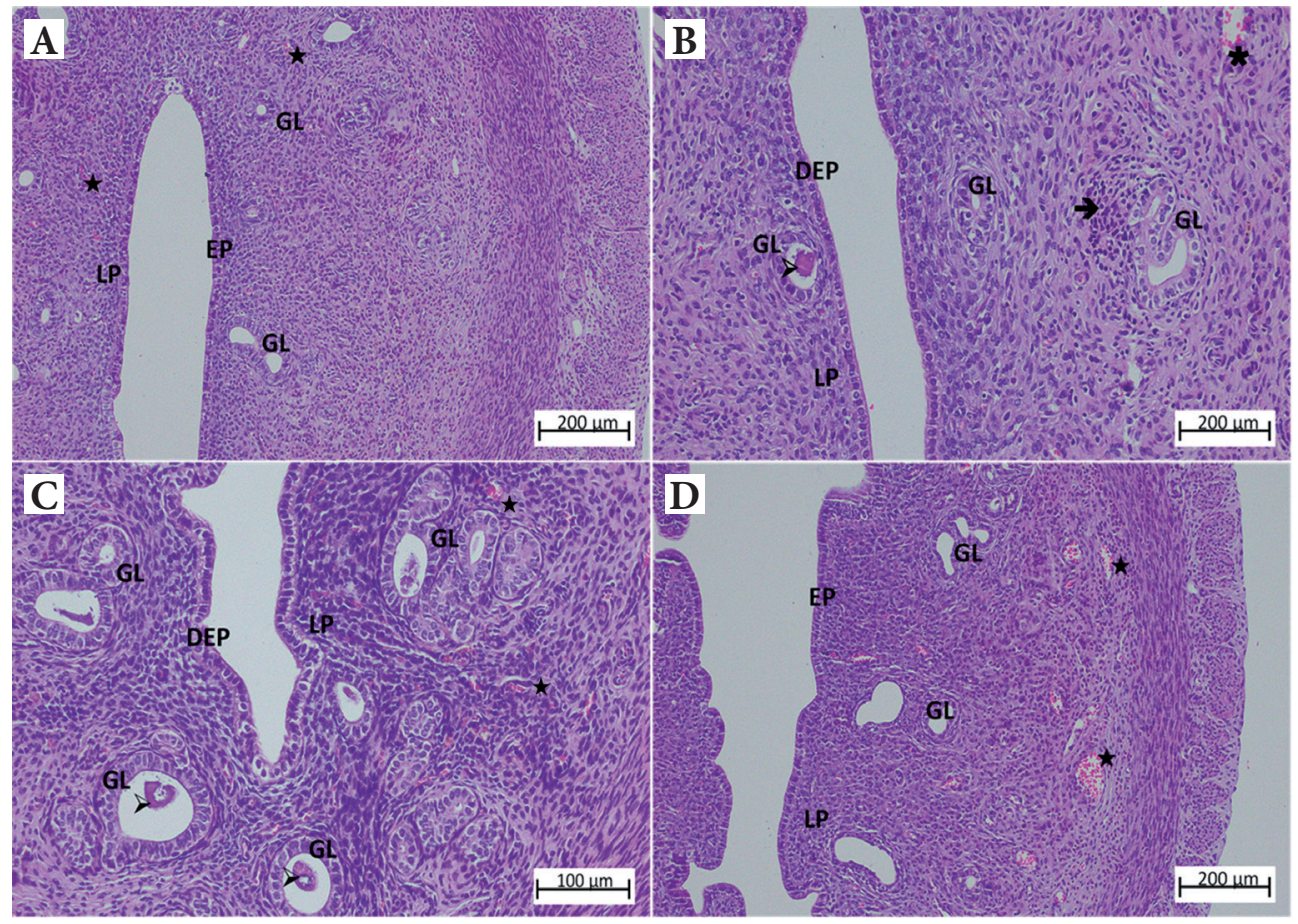

Figure 4. The histological findings of the uterine tissue. A. Control group (H\&E, 100× magnification). B. Ketamine group (H\&E, 100× magnification). C. Ketamine group (H\&E, 200× magnification). D. Ketamine+nimesulide group (H\&E, 100× magnification). DEP, pericellular edema and degeneration in epithelium; EP, epithelium; GL, uterine gland; LP, lamina propria; > vacuolised bodies; $\rightarrow$ inflamatuar cell infiltration; $\star$ congested blood vessel. 


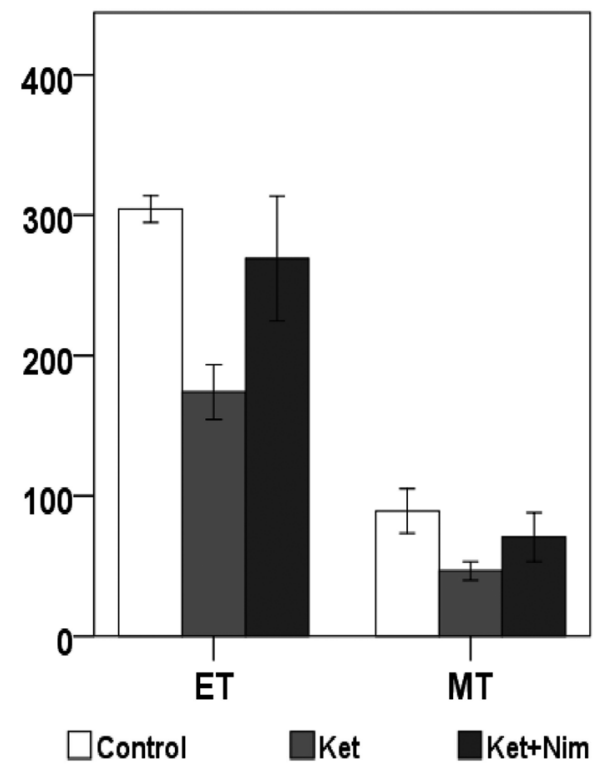

Figure 5. The averages of endometrial (ET) and myometrial thickness (MT) in the study groups. Control, healthy control group; Ket, ketamine group; Ket+Nim, ketamine+nimesulide group. Data are mean \pm SD

the present study was to demonstrate the ketamine-induced uterine and ovarian damage for the first time in the literature, and to examine the efficacy of nimesulide in preventing this damage. This study was designed to see how ketamine acts on uterine and ovarian tissues and how to eliminate its side effects. However, we know from previous animal studies that ketamine causes oxidative stress in the tissues and this can be prevented by nimesulide (Suleyman et al. 2008; Onaolapo et al. 2018).

Onaolapo et al. (2018) showed that subchronic ketamine use changes brain morphology and the behaviors of rats by increasing glutamate levels. Accordingly, oxidative stress and caspase-3-mediated apoptosis increased in the brain tissue. They used different ketamine dosages $(7.5,15$ or $30 \mathrm{mg} /$ $\mathrm{kg}$ daily) for 8 weeks. MDA concentration increased in the groups where ketamine was used, compared to the control group, while SOD and GSH activity significantly decreased in those groups. In that study, neurodegenerative changes were seen histopathologically in the brain tissue of the group using ketamine, while morphological changes have shown brain damage in this study.

The effects of ketamine are dose-dependent. Intramuscular doses of 3-4 mg/kg are typically used by emergency physicians to induce sedation. A typical recreational dose of ketamine is $100-200 \mathrm{mg}$ (Weiner et al. 2000). As the tolerance to ketamine develops, the daily dose of ketamine can be increased up to $4 \mathrm{~g}$ (Lim 2003). For this study, ketamine was applied at a dosage of $60 \mathrm{mg} / \mathrm{kg}$ i.p., once a day for 30 days. Two oxidant (MDA, MPO) and two antioxidant (tGSH, SOD) parameters were analyzed biochemically, and their levels were examined in terms of 3 experimental groups. It was determined that the oxidant parameters increased in the groups treated with ketamine, but antioxidant parameters increased when nimesulide was applied to the same group. Our biochemical findings support published literature. The histopathological findings of our experimental animals also support our biochemical results. Thus, the side effects of oxidative stress caused by ketamine were biochemically and histopathologically confirmed in uterine and ovarian tissue.

Previous studies showed that nimesulide had a major antioxidant effect by depressing oxidative stress. Demiryilmaz et al. (2014) showed nimesulide's antioxidant effect at $50 \mathrm{mg} / \mathrm{kg}$ and $100 \mathrm{mg} / \mathrm{kg}$ doses on liver tissue. In our study, we applied nimesulide at a dosage of $50 \mathrm{mg} / \mathrm{kg}$ daily for 30 days. The examination of the Ket+Nim group revealed that tGSH and SOD levels increased and the morphological tissue damage caused by ketamine was corrected. It has been shown in previous animal studies that oxidative stress in the uterus decreases myometrial and endometrial thickness. Teixeira et al. (2014) showed that myometrial and endometrial thickness in the uterus decreases due to the decrease of estrogen in ovariectomized rats, and this can be prevented by soybean extract, which is a potent antioxidant. Oxidative stressinduced tissue damage and cell death are the main factors in decreasing endometrial and myometrial thickness. Although the endometrial thickness varies according to the stages of the menstrual cycle, myometrial thickness decreases, which is the strongest evidence of tissue damage caused by oxidative stress. In our study, we proved that the negative effects of ketamine can be corrected with nimesulide by comparing the myometrial and endometrial thicknesses between the groups. This histological result in our study supported the published literature, and it was statistically significant.

There were some restrictions of our experiment. Firstly, there is no data about the alleviating effect of nimesulide on ketamine-induced uterine and ovarian injury in the published literature. Secondly, the usual nimesulide dose is 100 $\mathrm{mg}$, twice a day, for adults, and $5 \mathrm{mg} / \mathrm{kg}$ of body weight in 2 or 3 divided doses for children. Nimesulide was administered to the rats between 10 and $200 \mathrm{mg} / \mathrm{kg}$ dosages at the previous experimental studies (Suleyman et al. 2007; Borkotoky et al. 2014). The present study adopted a single dose of nimesulide $(50 \mathrm{mg} / \mathrm{kg}$ ) for the experiment. Different doses of nimesulide must be applied in the studies to examine the mean effective dose for rats and humans. Thirdly, ketamine-induced uterine and ovarian injury was demonstrated by the morphological modifications in both types of tissue. This damage must be evaluated in the other organs and systems by future studies. Fourthly, the results of experimental studies on animals should not be extrapolated to humans. 
In conclusion, this study showed that nimesulide treatment was highly beneficial in preventing ketamine-induced inflammation and oxidative stress in uterine and ovarian tissues. Antioxidant molecules such as nimesulide may protect against the damage caused by ketamine to the genital organs in young women. Prospective clinical studies about the fertility capacity of female abusers using ketamine will provide more important data on the importance of this issue.

Acknowledgement. We thank Professor Halis Suleyman of the Department of Pharmacology in the Faculty of Medicine at Erzincan Binali Yıldırım University for his technical support and suggestions.

Conflict of interest. The authors report no conflicts of interest. Also, we hereby acknowledge that this study was self-funded by the authors.

Authorship contributions. Research concept and design: CT, RM and GNY; collection and/or assembly of data: CT, RM, GNY and MS; data analysis and interpretation: CT, RM and TO; writing the article: CT, EY, TO and SK; critical revision of the article: EY, TO, SK, MS and CT; final approval of article: GNY, SK, MS, EY and CT.

\section{References}

Ahiskalioglu EO, Aydin P, Ahiskalioglu A,Suleyman B, Kuyrukluyildiz U, Kurt N, Altuner D, Coskun R, Suleyman H (2018): The effects of ketamine and thiopental used alone or in combination on the brain, heart, and bronchial tissues of rats. Arch. Med. Sci. 14, 645-654 https://doi.org/10.5114/aoms.2016.59508

Aksoy M, Ince I, Ahiskalioglu A, Dostbil A, Celik M, Turan MI, Cetin N, Suleyman B, Alp HH, Suleyman H (2014): The suppression of endogenous adrenalin in the prolongation of ketamine anesthesia. Med. Hypotheses 83, 103-107 https://doi.org/10.1016/j.mehy.2014.03.033

Arslan A, Ozcicek A, Suleyman B, Coban TA, Cimen FK, Nalkiran HS, Kuzucu M, Altuner D, Cetin N, Suleyman H (2016): Effects of nimesulide on the small intestine mucositis induced by methotrexate in rats. Exp. Anim. 65, 329-336 https://doi.org/10.1538/expanim.15-0122

Borkotoky D, Panda SK, Sahoo GR, Parija SC (2014): Genotoxicity of nimesulide in Wistar rats. Drug Chem. Toxicol. 37, 178-183 https://doi.org/10.3109/01480545.2013.834357

Bradley PP, Priebat DA, Christensen RD, Rothstein G (1982): Measurement of cutaneous inflammation: estimation ofneutrophil content with an enzyme marker. J. Invest. Dermatol. 78, 206-209 https://doi.org/10.1111/1523-1747.ep12506462

Craven R (2007): Ketamine. Anaesthesia 62 (Suppl. 1), 48-53 https://doi.org/10.1111/j.1365-2044.2007.05298.x

Dalgarno PJ, Shewan D (1996): Illicit use of ketamine in Scotland. J. Psychoactive Drugs 28, 191-199 https://doi.org/10.1080/02791072.1996.10524391

Demiryilmaz I, Turan MI, Kisaoglu A, Gulapoglu M, Yilmaz I, Suleyman H (2014): Protective effect of nimesulide against hepatic ischemia/reperfusion injury in rats: effects on oxidant/ antioxidants, DNA mutation and COX-1/COX-2 levels. Pharmacol. Rep. 66, 647-652

https://doi.org/10.1016/j.pharep.2014.02.015

Dong H, Yang C, Shen Y, Liu L, Liu M, Hao W (2019): Effects of ketamine use on psychotic disorders and symptoms in male, methamphetamine-dependent subjects. Am. J. Drug. Alcohol. Abuse 45, 276-284 https://doi.org/10.1080/00952990.2018.1559849

Freese TE, Miotto K, Reback CJ (2002): The effects and consequences of selected club drugs. J. Subst. Abuse Treat. 23, 151-156 https://doi.org/10.1016/S0740-5472(02)00267-2

Hašková $\mathrm{P}$, Koubková L, Vávrová A, Macková E, Hrušková K, Kovaříková P, Vávrová K, Simůnek T (2011): Comparison of various iron chelators used in clinical practice as protecting agents against catecholamine-induced oxidative injury and cardiotoxicity. Toxicology 289, 122-131

https://doi.org/10.1016/j.tox.2011.08.006

Isaoglu U, Yilmaz M, Sener E, Cetin N, Altuner D, Bilen H, Yapca OE, Demiryilmaz I, Isaoglu I, Gul MA (2012): The impaired balances of oxidant/antioxidant and COX-1/COX-2 in ovarian ischemia-reperfusion injury and prevention by nimesulide. Lat. Am. J. Pharm. 31, 1481-1488

Khan SA, Ahmad M, Kousar R, Murtaza G (2011): Nimesulideserratiopeptidase sustained release microparticles - combined formulation and in vitro characterization. Adv. Clin. Exp. Med. 20, 605-611

Lim DK (2003): Ketamine associated psychedelic effects and dependence. Singapore Med. J. 44, 31-34

Ohkawa H, Ohishi N, Yagi K (1979): Assay for lipid peroxides in animal tissues by thiobarbituric acid reaction. Anal. Biochem. 95, 351-358 https://doi.org/10.1016/0003-2697(79)90738-3

Onaolapo AY, Ayeni OJ, Ogundeji MO, Ajao A, Onaolapo OJ, Owolabi AR (2018): Subchronic ketamine alters behaviour, metabolic indices and brain morphology in adolescent rats: Involvement of oxidative stress, glutamate toxicity and caspase3-mediated apoptosis. J. Chem. Neuroanat. 96, 22-33 https://doi.org/10.1016/j.jchemneu.2018.12.002

Ozturk AM, Ergun MA, Demir T, Gungor I, Yilmaz A, Kaya K (2014): Ketamine is toxic to chondrocyte cell cultures. Bone Joint J. 96-B, 989-994 https://doi.org/10.1302/0301-620X.96B7.33005

Sedlak J, Lindsay RH (1968): Estimation of total, protein-bound, and nonprotein sulfhydryl groups in tissue with Ellman's reagent. Anal. Biochem. 25, 192-205 https://doi.org/10.1016/0003-2697(68)90092-4

Suleyman H, Halici Z, Cadirci E, Hacimuftuoglu A, Keles S, Gocer F (2007): Indirect role of alpha2-adrenoreceptors in anti-ulcer effect mechanism of nimesulide in rats. Naunyn. Schmiedebergs. Arch. Pharmacol. 375, 189-198 https://doi.org/10.1007/s00210-007-0151-0

Suleyman H, Cadirci E, Albayrak A, Halici Z (2008): Nimesulide is a selective COX-2 inhibitory, atypical non-steroidal antiinflammatory drug. Curr. Med. Chem. 15, 278-283 https://doi.org/10.2174/092986708783497247

Sun Y, Oberley LW, Li Y (1988): A simple method for clinical assay of superoxide dismutase. Clin. Chem. 34, 497-500 
Teixeira CP, Simões RS, Santos MA,Calió ML, Soares JM, Jr, Simões MJ, Bertoncini CR, Higa EM, Carbonel AF (2014): Soybean concentrated extract counteracts oxidative stress in the uterus of rats. Climacteric 17, 402-409

https://doi.org/10.3109/13697137.2013.856402

Velioglu C, Erdemli ME, Gul M, Erdemli Z, Zayman E, Bag HG, Altinoz E (2019): Protective effect of crocin on food azo dye tartrazine-induced hepatic daage by improving biochemical parameters and oxidative stress biomarkers in rats. Gen. Physiol. Biophys. 38, 73-82

https://doi.org/10.4149/gpb_2018039
Weiner AL, Vieira L, McKay CA, Bayer MJ (2000): Ketamine abusers presenting to the emergency department: a case series. J. Emerg. Med. 18, 447-451 https://doi.org/10.1016/S0736-4679(00)00162-1

White JM, Ryan CF (1996): Pharmacological properties of ketamine. Drug Alcohol Rev. 15, 145-155

https://doi.org/10.1080/09595239600185801

Received: February 21, 2019

Final version accepted: June 3, 2019

First published online: August 14, 2019 